\begin{tabular}{|c|c|c|}
\hline & $\begin{array}{l}\text { European Association for the } \\
\text { Development of Renewable Energies, Environment } \\
\text { and Power Quality (EA4EPQ) }\end{array}$ & $\begin{array}{l}\text { International Conference on Renewable Energies and Power Quality } \\
\text { (ICREPQ'12) } \\
\text { Santiago de Compostela (Spain), 28th to 30th March, } 2012\end{array}$ \\
\hline
\end{tabular}

\title{
Dynamic Modeling and Analysis of Fuel Cell Powered Electric Vehicle
}

\author{
Osama A. Al-Naseem ${ }^{1}$ and Mohamed A. H. El-Sayed ${ }^{2}$ \\ ${ }^{1,2}$ Electrical Engineering Department \\ College of Engineering and Petroleum, Kuwait University \\ Kuwait \\ ${ }^{1}$ Phone:+965 24985921, e-mail: eng.osama.ku@gmail.com \\ ${ }^{2}$ Phone:+965 24983347, e-mail: elsmah@ @otmail.com
}

\begin{abstract}
An Electric Vehicle is digitally simulated and presented in this paper. The proposed electric vehicle scheme has four key subsystems to ensure stabilized driving speed. The first subsystem includes Fuel Cell as clean energy resource. The second is the deriving electric motor of the vehicle. The third is the interfacing converters between the energy resource and the driving motor. The fourth subsystem is the control strategy to adjust the hydrogen rate to the fuel cell and to regulate the motor speed to follow up the vehicle load. The different vehicle configurations using either DC or AC motor, PID, Sliding Mode (SM) and direct torque Controllers (DTC) are digitally simulated and compared using Matlab/Simulink/Sim-Power software environment to validate the vehicle performance under varying speed and to justify the appropriate vehicle configuration.
\end{abstract}

\section{Key words}

Fuel Cells, PID controllers, sliding mode control, converters, DTC control, Electric Vehicle.

\section{Introduction}

The transportation sector represents one of the large fossil fuel consumers in a form of petroleum products. The combustion of these products is a major contributor to green-house gases. Therefore, recent studies concentrate on how to utilize environmental friendly renewable resources to develop new drive technologies for vehicle powers [1-3]. Consequently, the market of electric vehicle using fuel cell as driving power is beginning to grow and mature in an encouraging ways.

A fuel cell is an electrochemical device which combines a fuel (e.g. hydrogen, methanol) and oxygen to produce a direct current. Unlike storage batteries fuel cells can be continuously fed with a fuel so that the electrical power output is sustained for a longer period of time. There are numerous applications for fuel cells today and depending on the specific application, different types of fuel cells are now available in the market $[4,5]$.
For automotive applications it is desirable to have a fuel cell system with a low operating temperature. PEM fuel cells, because of their low cost, ease of operation, lower operating temperature and higher energy density, are good candidate for driving electric vehicles $[6,7]$.

This paper is concerned with the dynamic modeling and analysis of fuel cell powered vehicles using hydrogen as energy source. Of particular interest will be how the characteristics of the driving motor and the applied control strategy can enhance the vehicle performance under different speed changes. Therefore, the electric vehicle behavior is studied using either $\mathrm{DC}$ or $\mathrm{AC}$ motor for driving the required powertrain with different control strategies. The different vehicle configurations are evaluated using detailed simulation results. The description of the studied electric vehicle is given in section II after the introduction. In section III the modeling of the fuel cell together with the interfaced converters are presented. In section IV the control strategy of the different subsystems are summarized. Simulation results are given in section $\mathrm{V}$ and the paper ends with final conclusions.

\section{Description of the Studied Electric Vehicle}

The studied electric vehicle utilizes hydrogen as energy source to the fuel cell stack. This vehicle has other key subsystems such as traction motor interfacing converters and vehicle management and control unit required for efficient vehicle operation.

Fuel cells are also scalable and can be stacked until desired voltage and power output is reached. Since fuel cells operate silently, they reduce noise and pollution as well as the waste heat from the cell can be used to provide hot water or heating of vehicle space. The driving DC motor is controlled via DC/DC converter. On the other 
side, the speed of driving induction motor is regulated via direct torque control scheme.

\section{Modeling of Electric Vehicle}

\section{A. Fuel Cell Model}

Each individual fuel cell unit in the stack has two electrodes, one positive (anode) and one negative (cathode). The reactions responsible for producing electricity take place at these electrodes. The electrolyte in the cell carries electrically charged particles from one electrode to the other. Thereby, the electrolyte permits only the appropriate ions to pass between the anode and cathode.

Fuel cells have a non-linear characteristic that can significantly influence system operation due to chemical reaction polarization. The three fuel cell polarization losses can be summarized as Irreversible/activation polarization loss, Concentration polarization loss, and Ohmic or resistance polarization.

The activation polarization is directly related to the rates of electrochemical reactions [5,6]. In addition, ohmic losses occur due to the resistance of ions flow in the electrolyte and electrode materials. The ohmic losses in the electrolyte can be reduced by decreasing the electrode separation and enhancing the ionic conductivity of the electrolyte. As a reactant is consumed at the electrode by electrochemical reaction, there is a loss of potential due to the inability of the surrounding material to maintain the initial concentration of the bulk fluid. This will result in a concentration gradient which initiates slow diffusion for the gas phase in the electrode pores, solution/dissolution of reactants/ products into/out of the electrolyte, or diffusion of reactants/products through the electrolyte to/from the electrochemical reaction site [5]. At practical current densities, slow transport of reactants/products to/from the electrochemical reaction site is a major contributor to concentration polarization and its associated losses are expressed by $[5,6]$ :

$\eta_{\text {conc }}=\frac{R T}{n F} \ln \left(1-\frac{i}{i_{L}}\right)$

Where

$\eta_{\text {conc }}:$ the concentration losses

$i_{L}, \mathrm{~F}$ : the limiting current, Faraday constant

The above mentioned activation and concentration polarization can exist at both the positive (anode) and negative (cathode) electrodes in fuel cells. Therefore, the total losses at these electrodes is the sum of $\eta_{\text {act }}$ and $\eta_{\text {conc }}$ as follows

$$
\begin{aligned}
& \eta_{\text {anode }}=\eta_{\text {act }, a}+\eta_{\text {conc }, a} \\
& \eta_{\text {cathode }}=\eta_{\text {act }, c}+\eta_{\text {conc }, c} \\
& \mathrm{~V} \text { cell }=\mathrm{E} \text { cathode }-\eta_{\text {cathode }}-\left(\text { Eanode }+\eta_{\text {anode }}\right)-\mathrm{i} \mathrm{R}_{\mathrm{fc}}
\end{aligned}
$$

The basic DC motor state equations assuming constant flux are:

$$
\begin{aligned}
& \frac{d i_{a}}{d t}=\frac{1}{L_{a q}}\left(V_{t}-K_{m} \omega_{m}-i_{a} R_{a}\right) \\
& \frac{d \omega_{m}}{d t}=\frac{1}{J}\left(K_{m} i_{a}-B \omega_{m}-T_{L}\right)
\end{aligned}
$$

\section{(2) Induction Motor}

The IM model in a stationary reference frame can be written in space vector notation as:

$\vec{v}_{s}=R_{s} \vec{i}_{s}+\frac{d \vec{\psi}_{s}}{d t}$

$$
\begin{gathered}
\vec{v}_{r}=0=R_{r} \vec{i}_{r}+\frac{d \vec{\psi}_{r}}{d t}-j \omega_{r} \vec{\psi}_{r} \\
J \frac{d \omega_{r}}{d t}+f_{v} \omega_{r}=T_{e}-T_{l} \\
T_{e}=\frac{3}{2} p\left(\vec{i}_{s} \times j \vec{\psi}_{s}\right)
\end{gathered}
$$

\section{(3) Buck-Boost Converter}

The circuit diagram of the buck-boost converter is shown in Figure (1). Assuming lossless converter [8]

$\frac{V_{o}}{V_{i}}=-\frac{D}{(1-D)}$

This means that the buck-boost converter operates as a set-up converter when $D>0.5$, and operates as a stepdown converter when $\mathrm{D}<0.5$.

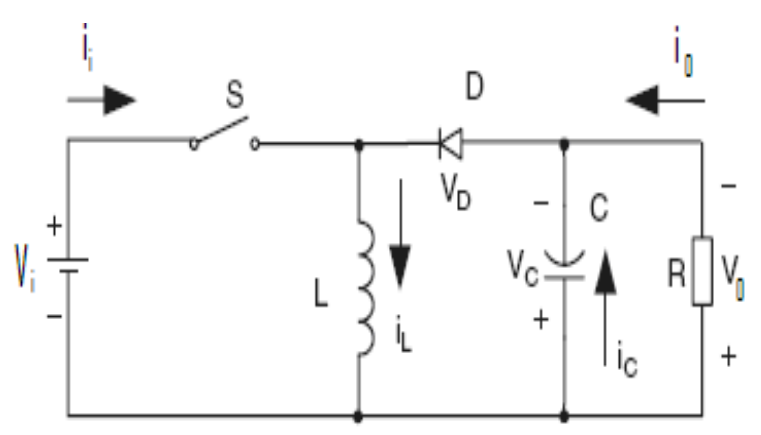

Fig. (1) Buck-boost converter circuit diagram

B. Modeling of the driving motor (1) DC Motor 
For two modes of converter operations the corresponding state equations during $t_{\text {on }}$ and $t_{\text {off }}$ where $\mathrm{X}_{1}=\mathrm{I}_{\mathrm{L}}, \mathrm{X}_{2}=\mathrm{V}_{\mathrm{C}}$, are given as follows:

$$
\begin{aligned}
& {\left[\begin{array}{c}
\dot{X}_{1} \\
\dot{X}_{2}
\end{array}\right]=\left[\begin{array}{cc}
0 & 0 \\
0 & 0
\end{array}\right]\left[\begin{array}{l}
X_{1} \\
X_{2}
\end{array}\right]+\left[\begin{array}{cc}
\frac{1}{L} & o \\
0 & -\frac{1}{c}
\end{array}\right]\left[\begin{array}{l}
V_{i} \\
i_{o}
\end{array}\right]} \\
& {\left[\begin{array}{c}
\dot{X}_{1} \\
\dot{X}_{2}
\end{array}\right]=\left[\begin{array}{cc}
0 & -\frac{1}{L} \\
\frac{1}{C} & 0
\end{array}\right]\left[\begin{array}{l}
X_{1} \\
X_{2}
\end{array}\right]+\left[\begin{array}{cc}
0 & o \\
0 & -\frac{1}{C}
\end{array}\right]\left[\begin{array}{l}
V_{i} \\
i_{o}
\end{array}\right] .}
\end{aligned}
$$

\section{Control strategy}

Two PID and SM controllers are implemented to control $\mathrm{H}_{2}$ flow rate according to difference in the current between fuel cell and motor. Sliding mode control provides large-signal stability, robustness, good dynamic response and is widely implemented for speed control of electric motor. In such cases, the converter switches are driven as a function of the instantaneous values of the system state variables to force its response to stay on the sliding surface [9].

In case of DC motor driven vehicle the PI controller is used for speed control, while the direct torque control (DTC) technique is applied for speed regulation of induction motor. In DTC the estimated values of the torque and flux are calculated based on the sampled motor's voltages and currents. Output of this estimator together with the stator flux orientation is used to select the appropriate voltage vectors of a three phase voltage source inverter [10, 11]. Consequently, DTC drive consists of DTC controller, torque and flux estimator and a voltage source inverter (VSI).

\section{Simulation results}

The proposed electric vehicle is modeled and simulated using Matlab/Simulink environment. The integrated supply system model is subject to step speed changes. Two basic independent controllers regulate the operation of the fuel cell and the electronic interface converters to the driven motor.

Figures $(2,5)$ show the digital simulation of dynamic responses of fuel cell power and motor speed using PID and sliding mode control of hydrogen flow rate. $d$ and more stable by implementing SM control Compared to the conventional PID controller. The settling time of the DC motor speed is reduced from 4 to 2 sec using sliding mode control.

For DTC control, Figures $(6,7)$ show the induction motor speed and motor stator current, respectively. From the speed response, the motor speed reaches its set value of $1000 \mathrm{rpm}$ in one second without any overshoot compared to the PID controller. The RMS value of induction motor current is reduced to $170 \mathrm{~A}$.

The results of DTC induction motor control validate the robustness fuel cell powered electric vehicle scheme. It is clearly shown that the implemented DTC can ensure maximum utilization and voltage stabilization with acceptable steady state error.

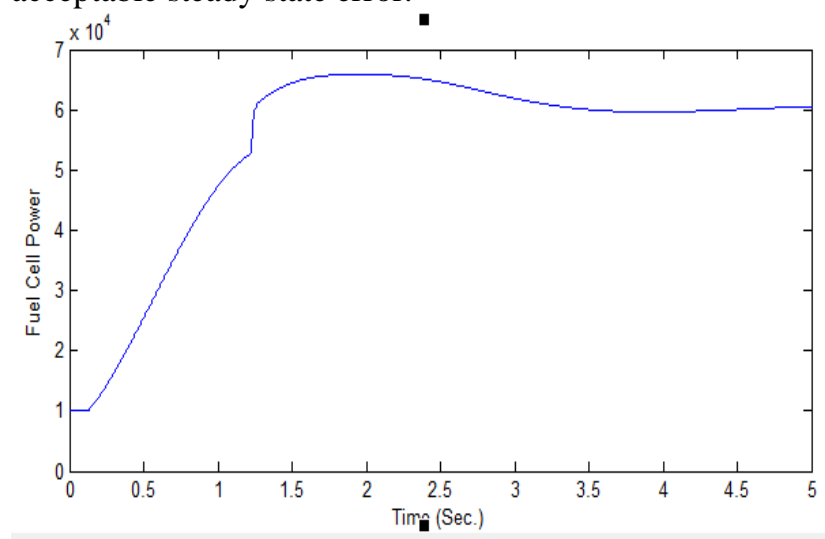

Fig. (2) Fuel cell power using PID controller

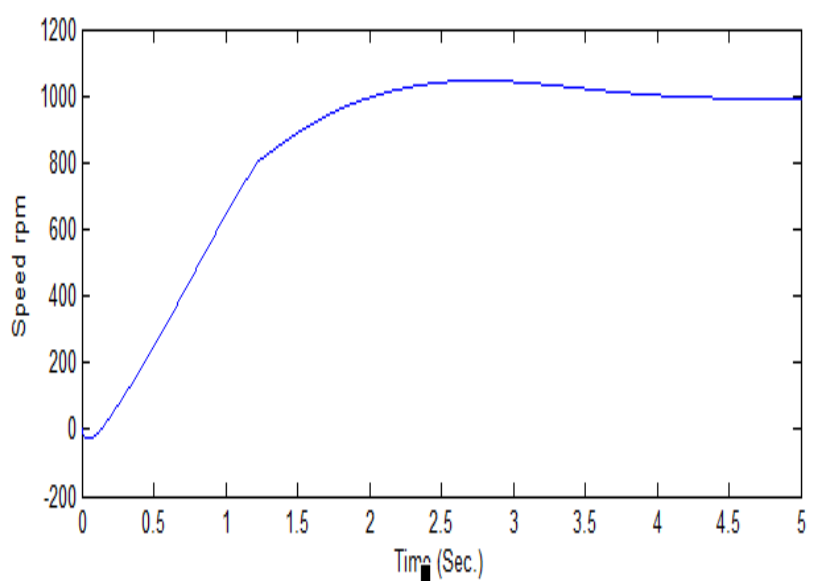

Fig. (3) DC motor speed using PID controller

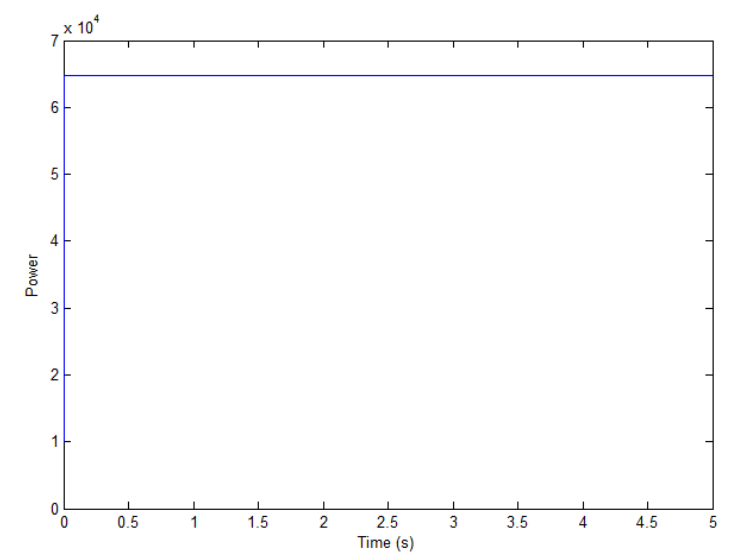

Fig. (4) Fuel cell power using sliding mode controller 


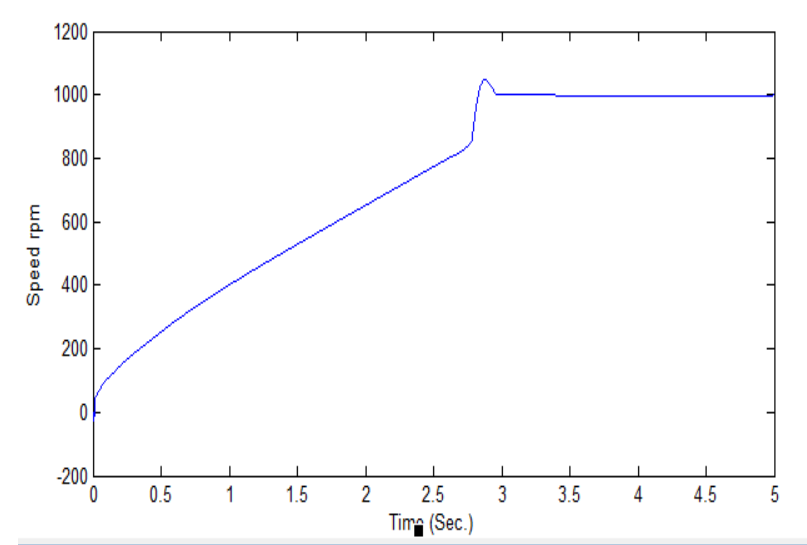

Fig.(5) DC motor speed using sliding mode controller

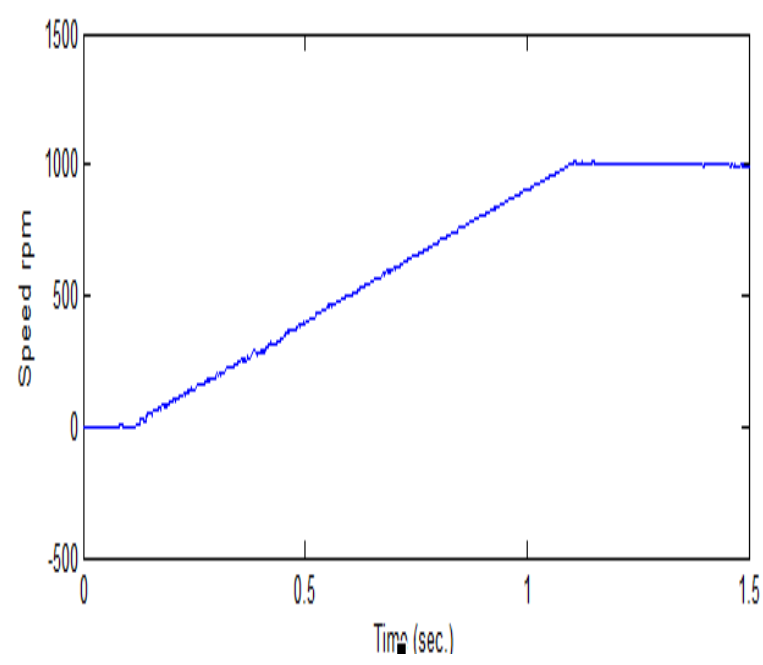

Fig. (6) Induction motor speed using DTC

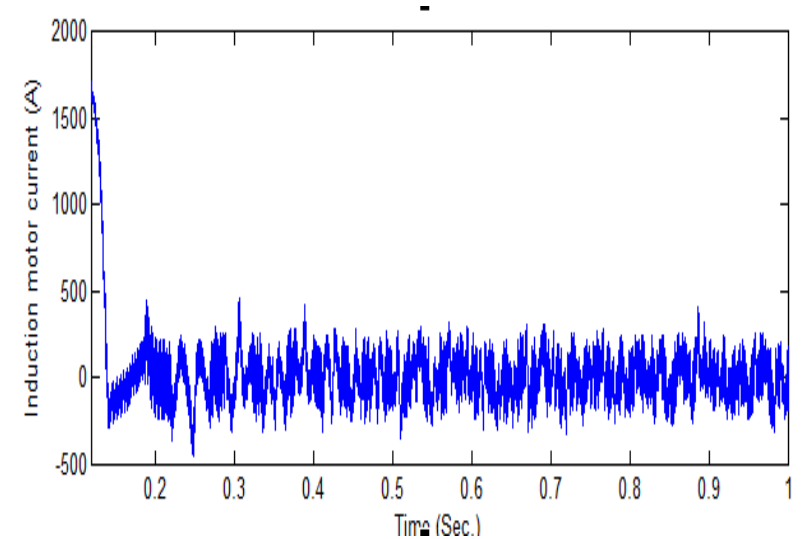

Fig. (7) Stator current of IM using DTC control

\section{Conclusions}

The research in Hybrid electric Vehicles using PEM-Fuel cell hydrogen technology is essential as the reliance on Fossil fuel as the main energy source in Transportation
Sector would affect the environment through harmful gas emission. The paper presents an integrated model of electric vehicle powered by fuel cell as clean energy source. In addition to the fuel cell, The electric vehicle scheme comprises interface converters to the electric motor. Two basic independent controllers regulate the operation of the fuel cell and the electronic interface converters to the driven motor. The electric vehicle behavior was studied using DC and AC motor for driving the required powertrain.

. The simulation results indicated that the sliding mode control showed good performance to the conventional PID controller in regulating the hydrogen flow rate to the fuel cell. The DTC scheme indicated an enhancement of the system performance. The electric vehicle operation using DTC control scheme controller scheme is fully validated for step speed change to ensure maximum utilization and voltage stabilization with acceptable steady state error.

\section{References}

[1] Demirdöven, N. \& Deutch, J., Hybrid Cars Now, Fuel Cell Cars Later, Science, vol. 305, 2004

[2] Husain, I., Electric and Hybrid Vehicles. Design Fundamentals, CRC Press LLC, ISBN 0-8493-1466-6, 2003

[3] Matsumoto, T., Watanabe, N., Sugiura, H. \& Ishikawa, T., Development of Fuel-Cell Hybrid Vehicle, Society of Automotive Engineers, 2002-01-0096, 2002

[4] Iqbal Husain, Electric and Hybrid Vehicles Design Fundamental, Boca Raton London New York Washington, D.C., ISBN 0-8493-1466-6, 2005.

[5] EG\&G Technical Services, Inc., Fuel Cell Handbook (Seventh Edition), U.S. Department of Energy Office of Fossil Energy, National Energy Technology Laboratory P.O. Box 880, Morgantown, West Virginia 26507-0880, November 2004.

[6] S. Nawar, " Design and Control of Fuel Cell for Transportation Application", M Sc Thesis, Cairo University, Faculty of Engineering, 2009, (Supervisors: M. El-Sayed, ... eta)

[7]T. Lipman, "Hybrid Electric And Fuel Cell Vehicle Technological Innovation: Hybrid and Zero-Emission Vehicle Technology Links, 20th International Electric Vehicle Symposium and Exposition, November 15-19, 2003 , Long Beach, California

[8] J.-H. Su, J.-J. Chen, D.-S. Wu "Learning feedback controller design of switching converters via Mat lab/Simulink" IEEE Transaction on Education, vol. 45, Nov. 2002.

[9] R. Venkataramanan, "Sliding mode control of power electronics", Ph.D. Thesis, California Institute of Technology, 1986.

[10] P.Tiitinen, "The next generation motor control method, DTC direct torque control", Proceeding of Int. Conf on Power Electronics, Drives and Energy System for industrial growth, N.Delhi, India, 8-11 Jan., 1996

[11] Georgios Papafotiou, Tobias Geyer and Manfred Morari, “ Optimal Direct Torque Control of Three-Phase Symmetric Induction Motors 43rd IEEE Conference on Decision and Control December 14-17, 2004 Atlantis, Paradise Island, Bahamas 